\title{
THE IMPACT OF LEARNING ORIENTATION ON FINANCIAL PERFORMANCE WITH NON-FINANCIAL PERFORMANCE AS A MEDIATING VARIABLE
}

\author{
Vicky F Sanjaya ${ }^{1)}$ \\ email: Vickyfsanjaya3@gmail.com \\ 1) Manajemen, Universitas Teknokrat Indonesia \\ Jl. H.ZA Pagaralam, No 9-11, Labuhanratu,Bandarlampung \\ Email:pertama@gmail.com ${ }^{1)}$,kedua@ymail.com ${ }^{2)}$,ketiga@teknokrat.ac.id ${ }^{3)}$
}

\begin{abstract}
This study aims to see the impact of learning orientation on the performance of companies in financial and nonfinancial, and see the role of non-financial performance as a mediating variable. No relevant profit theory and still limited research that saw the company's performance from both sides of the financial and nonfinancial to be a gap for doing research. The sample in this study is small and medium enterprises (SMEs) domiciled in the Province of Yogyakarta (DIY). The number of samples studied is as many as 113 respondents consisting of five districts / cities in DIY. The results of this study indicate that the orientation of learning has a positive and significant impact on financial performance and non-financial companies. In addition, this study also gives results that non-financial performance mediates some of the relationship between learning orientation to financial performance.
\end{abstract}

Keywords: learning orientation, financial performance, non-financial performance, SMEs.

\section{Introduction}

\subsection{Background}

The complexity and high turbulence of today requires every company to have the right strategy, to face competitive competition. (Palmer and Hardy, 2000) say that learning activities are one of the important strategic aspects to face competitive competition in order to achieve the company's competitive advantage. Learning itself has a definition that is an important process whereby individuals within the organization are able to gain new knowledge and can improve behaviors and actions taken to a better direction, as Stata says:

"Learning as a process by which the individual gain new knowledge and insight and thereby modifiy their behavior and actions (1989) p: 65

In learning there is one important part of concern that is the orientation of learning (Zhou et al., 2015). Learning orientation is a strategic aspect in which individuals within a company have a level of commitment to learn, share vision and use open thinking within the organization (Nybakk, 2012; Bature and Hin, 2017). Learning orientation is also a vast activity of creating and using knowledge to achieve the company's competitive advantage as Zhou, et al:

Learning orientation refers to organization wide activity of creating and using knowledge to enhance competitive advantage, 2015, p: 275.

When the individual has three instructional orientation indicators: commitment to learning, shared vision and open-ended attitudes are expected to be their driving force in improving and modifying their behavior in a better direction as Stata (1989) argues and supporting in the creation and use of knowledge Zhou et al., (2015) which will serve as a driver for improving the company's performance.

\subsection{Research Problem}

The company's own performance according to (Neely, 1999; Bature and Hin, 2017) is divided into two nonfinancial performance and financial performance. Other researchers Rauch et al., (2009) support the argument and say that the company's performance measurement should look at both sides, both nonfinancial and financial. Measuring company performance using non-financial and financial aspects can provide a holistic overview of operational activities and the dynamics of information that allows to create observations on the progress of sustainable performance over a period of time (Maduekwe and Kamala, 2016). According to Zigan \& Zeglat (2010) measurements that only use financial performance fail to see business performance, corporate strategy and can be counterproductive for the company in the long-term aspect. Another researcher Kaplan (2012) explains that when only performance measurements performed from the financial aspect cannot capture the long-term benefits of the current manager's decision. Previous research related to the influence of learning orientation and corporate performance unfortunately focuses more on general business performance without sharing financial and nonfinancial performance.

Based on observations in some previous studies are still a few who try to discuss non-financial performance variables as a variable of mediation between learning orientation and financial performance. Some of these 
studies include $\mathrm{Li}$ and $\mathrm{Li}$ (2006) using knowledge management, (Calantone et al., 2002; Nybakk, 2012; Serna et al., 2016) using a variable of firm innovation, and more research sees a direct influence between learning orientation on financial performance (Wang and Wei, 2005; Prieto and Revilla, 2006; Kaplan et al., 2014; Amen, 2015). Referring to research (Kaplan, 2012: Gallani et al., 2015) it is said that non-financial performance can be a mediator and a driver of profitability in financial, competitive strength and long-term strategic goals of the company. Therefore, to cover the existing gap, researchers try to see the mediation role of nonfinancial performance between learning orientation and financial performance.

Learning orientation is one step that can be done to help create a competitive advantage for (SMEs) that will support the improvement of the resulting performance. In general, previous studies on performance measurement on SMEs are still very rare to see from the financial and non-financial (Maduekewe, 2015). The same thing is supported by research from Maduekwe and Kamala (2016) which says that non-financial and financial performance measurement in small and medium enterprises (SMEs) is very important to do. Furthermore, small firms are more dominated by informal learning that can increase flexibility and adaptation processes so that learning orientation in small firms is expected to have better results (Keskin 2006). Small and medium enterprises also have their own challenges to environmental turmoil and change, so the importance of a more effective learning orientation for companies (Frank et al., 2012).

\subsection{Objective}

Based on the discussion in the objective of this research are:

To look performance of the company between two sides, both non-finanacial and financial performance.

To examine the mediating non-financial performance between learning orientation and financial performance.

To examine the impact of learning orientation on performance os SMEs.

\section{Discussion}

The impact of learning orientation on financial performance

The learning orientation as described in the above background is a predictor of company performance. Learning orientation can be an individual driver within the organization to make improvements to various actions or activities undertaken (Nybakk, 2012). Research from Lopez et al., (2005) says that the orientation of learning has a significant positive impact on the financial performance of the company. Other researchers Frank et al., (2012) conducted a learningorientation test on financial performance at 228 SMEs in Australia. The results of his research said that the higher level of learning orientation in small and medium enterprises (SMEs) led to an increase in financial performance on SMEs. Other researchers Jiang and Li (2008) conducted a study of learning orientation on financial performance in the context of corporate strategic alliances. The results found were similar in terms of learning orientation has a significant positive effect on financial performance.

Wang (2008) said that with the activities of learning orientation will help companies in getting, disseminate and share various information in the company's activities. Other earlier studies that attempted to see the effect of learning orientation on fi nancial performance were (Sinkula, 1997; Calantone et al., 2002; Kropp et al., 2006) and found significant positive results between learning orientation and fi nancial performance. When individuals commit to learn, sharing visions and using open thinking is expected to create improvements in various aspects of corporate financial performance such as decreased operating costs, increased sales, increased profits, the company. So, based on the exposure as well as various studies that support the above authors make a hypothesis:

Hypothesis 1: Learning orientation has a positive effect on performance

finance.

2.3 The impact of learning orientation on non-financial performance

Tuan and Lwin (2013) conducted research on internal and external learning of the organization and looked at organizational learning in manufacturing companies in Myanmar. The results of his research said that when companies do learning activities have a positive influence on the performance of non-financial companies such as customer satisfaction, employee satisfaction, and supplier satisfaction. Another study of Maduekwe and Kamala (2016) explains that learning and development activities are one of the drivers in decreasing employee absenteeism and employee migration within the company.

Several other previous studies such as (Dimovski and Skerlavaj, 2004; Figueredo, 2003) say that learning activities have a positive and significant influence on nonfinancial performance of the company. Non-financial performance as explained by (Harif et al., 2013, Maduekwe and Kamala, 2016), among others, is the efficiency of employees, improvement of product and service quality, employee absenteeism and employee and customer satisfaction. As Nybakk (2012) points out, the orientation of learning leads individuals to have a commitment to change behavior and action in a better direction, share vision, and use open thinking. So when individuals in the company do orientation learning of course it will create a good change to various actions, such as more efficient work, decreased absenteeism, and create improvements to the quality of products and services produced.

Individuals who change their behavior and actions in a better direction will certainly have a sense of 
responsibility for their work. Such awareness will make improvements in the various activities of the work they do. Directly or indirectly it will make the activities more efficient, improve the quality of the products and services they produce and they will be more aware in responsible for the company. Based on that view and some previous research as described above the author makes a guess or hypothesis namely:

Hypothesis 2: Learning orientation has a positive effect on non-financial

performance

2.4 The impact of non-financial performance on financial performance

According to Atkinson et al., (1997) the main purpose of a company in doing business one of them to achieve financial and non-financial benefits. Gallani et al. (2015) in his article on the Harvard Business Review said that non-financial performance is a good indicator of the company's long-term financial performance. It is also supported by a statement from (Kaplan, 2012) that nonfinancial performance is important in achieving profitability, competitive strength and long-term strategic objectives. Indicators of non-financial performance aspects such as employee loyalty, employee satisfaction, internal processes and innovation are really aspects of the strategic drivers of value in modern business that produce future performance predictions (Hakkak and Ghodsi, 2015).

The opposite is precisely expressed since the classical era by Chakravarthy (1986) who said that non-financial performance has no relationship to the financial performance of the company. Dimovski and Skerlavaj (2004) in his research also said that non-financial performance has no effect on financial performance. Therefore, it is of interest to examine further the influence of non-financial performance and financial performance of the company.

Although there is a debate among some previous studies, it refers to Mr. and Lwin (2013) that non-financial performance is an outcome achieved by a company before it becomes a financial performance.

Several previous studies (Weisendanger, 1993: Hakkak and Ghodsi, 2015) found that improvements in quality, loyalty and employee satisfaction affect the profitability of the firm, Ittner and Larcker (1998) say that customer satisfaction has a significant effect on corporate profits, Lopez et al (2005) that non-financial performance indicators such as employee retention, quality improvement and reputation of the organization have a positive effect on the company's financial performance. Furthermore, other researchers like (Ciptono et al., 2011; Tuan and Lwin, 2013) also found similarly that nonfinancial performance has a significant impact on the financial performance of the company. So, it can be understood aspects of non-financial performance is a driver or supporter in realizing good financial performance.

In small and medium enterprises (SMEs) according to (Harif et al., 2013, Maduekwe and Kamala, 2016) that non-financial performance indicators such as improving product and service quality, employee efficiency and decreasing absenteeism become the driving force for improved financial performance. This is because when the company is able to produce non-financial performance such as good quality products and services will make consumers become satisfied and is expected to be loyal to the company thus creating increased profitability. Furthermore, with the increased efficiency of work performed by employees would greatly support the reduction of costs that are considered to be a burden on the company. Then the decline in employee absenteeism will make the company will be more productive so it is expected to increase sales of the company. Based on these views and previous research above the authors hypothesized:

Hypothesis 3: Non-financial performance has a positive effect on financial

performance.

2.5 Non-financial performance mediates the relationship between learning orientation to financial performance

Research from Tuan. and Lwin (2013) said that nonfinancial performance has a mediating role between internal learning activities within the company on the company's financial performance. Other researchers Prieto and Revilla (2006) explain that the role of nonfinancial performance to be a driver in improving the company's financial performance. While individuals within the company are learning by making behavioral changes and actions toward better ones such as having a commitment to learning, shared vision and open mindedness, this will certainly lead to improvements in non-financial performance aspects (Gallani et al., 2015). As explained by (Harif et al., 2013, Maduekwe and Kamala, 2016) that several indicators of non-financial performance include improvements in product and service quality, employee efficiency, decreased employee attendance and employee and customer satisfaction. When in the company there are improvements in product and service quality of course this will make consumers become more satisfied with the company, so it is expected to increase sales and profitability for the company. Individuals who are able to change their behaviors and actions for the better as more efficiently while doing the work and more diligent in work will certainly have an effect on reducing company costs. It is as described above that the existence of work efficiency and reduced attendance by employees will reduce the burdens that are not necessary for the company.

So we can understand that the improvement of financial performance cannot occur directly, but companies should be able to put emphasis on non-financial performance such as improving the quality of products and services, employee efficiency, and decreased employee absenteeism. Based on these views the author makes a hypothesis:

Hypothesis 4: Non-financial performance mediates the relationship between learning 
orientation and financial performance.

\section{A. Metode Analisis}

This research was conducted by using a survey research design and instrument in the form of questionnaire. Data collection in this research is done by cross sectional. Cross-sectional survey design is a study with data collection at a particular timeframe to produce important information about characteristics, attitudes and behavior (Leary, 2012). This study uses cross-sectional data collection because it is done within a certain time period aimed to see the effect of learning orientation on the performance produced at one point of time. The level in this study is the organizational level, in which the SME owner becomes the respondent of the research.

Sampling technique in research using purposive sampling technique. This study uses judgment sampling type because the selection of sample members conforms to several established criteria (Cooper and Schindler, 2014).

The validity of this research uses construct validity that is convergent validity by looking at factor loading factor of each item of a construct. Convergent validity is the level of a score on a scale correlated with scores on other scales intended to assess the same construct (Cooper and Schindler, 2014). Convergent validity will be measured using confirmatory factor analysis (CFA) with a minimum value of loading factor per item or indicator is $\geq 0.5$ (Hair et al., 2010). To test the reliability of internal consistency test used by using coefficient Cronbach's alpha (Cooper and Schindler, 2014).

The value of the cronbach's alpha coefficient of at least 0.70 though with a value of 0.60 is still acceptable (Hair et al., 2010).

Hypothesis testing using multiple linier regression analysis method using causal steps developed by (Baron and Kenny, 1986).

The result of validity test show that all items of questionnaire statement are valid. Minimum factor loading scores of all items have a minimum value of 0.537 . The result of the reliability test yields cronbach's alpha value above 0.7 which means that all variables are declared reliable.

\section{Kesimpulan}

The results of this test provide empirical evidence related to the influence of learning orientation on performance in SMEs in Yogyakarta. In this study found the result that the orientation of learning has a good influence on financial performance and non-financial performance of the company. Furthermore, this study also found that non-financial performance mediated some of the relationship between the effect of learning orientation on financial performance in this case on the context of SMEs. This finding may be a consideration for SME managers or owners to take into account the role of learning orientation as well as non-financial performance in the creation of improved financial performance.In addition, this study also reinforces a number of previous studies (Sinkula, 1997, Baker and Sinkula, 1999; Calantone Tuan and Lwin, 2013; Abdullahi et al., 2015; Bature and Hin, 2017) who emphasize that the importance of learning- improve

\section{Daftar Pustaka}

[1] Bashir, Usman., Ramay, Muhammad Ismail. 2010. Impact of Stress on Employees Job Performance. A Study on Banking Sector of Pakistan. International Journal of Marketing Studies. Vol. 2, No. 1.

[2] Belcourt, Monica. 2006. Outsourcing -The Benefit and The Risks. Human Resource and Management. Volume 16, Issue 2, Pages 269-279.

[3]Cheng, Ching-Yu., Liou, Shwu-Ru.,Chang, ChiaHao. 2015. Job stress and job satisfaction Among New Graduate Nurses During The First Year of Employment in Taiwan. International Journal of Nursing Practice. August 2015, vol. 21. Issue 4.

[4]Crampton, Suzanne, M., Hodge, J.W., Mishra, J.M. 1995. Stress and stress management. Journal of Advance Management, 60(3):2.

[5]Ganster, D.C., \& Schaubroeck, J. 1991. Work Stress and Employee Health. Journal of Management, 17, pp.235-271.

[6]Naseem, Khalida. 2018. Job Stress, Happiness and Life Satisfaction: The Moderating Role of Emotional Intelligence Empirical Study in Telecommunication Sector Pakistan. Journal of Social Sciences and Humanity Studies, 4(1)7-14.

[7]Marjani, A., Gharavi, A.M., Jahanshahi, M., Vahidirad, A., Allzadh, F. 2008. Stress among medical students of Gorgan (South East of Caspian Sea) Iran. Kathmandu University Medical Journal, 6(3):421-5.

[8]Ravinarayana, K.S., Ramakrishna, H. 2016. Impact Of Job Stress On Employee's Performance: An Empirical Study. Journal on management . Jun-aug2016, vol. 11 issue 1, p6-11. 6p.

[9]The National Institute of Occupational Safety and Health (NIOSH). 